\title{
STRUKTUR KOMUNITAS TERIPANG (HOLOTHUROIDEA) DI KAWASAN PANTAI DESA ONDONG KECAMATAN SIAU BARAT KABUPATEN SIAU TAGULANDANG BIARO'
}

\author{
Community Structure of Sea Cucumber (Holothuroidea) In the coastal areas of \\ Ondong village, west siau district, Siau-Tagulandang-Biaro Regency
}

\author{
Syafludin Lagio ${ }^{2}$, Lawrence J.L. Lumingas ${ }^{3}$, Gaspar D. Manu ${ }^{3}$
}

\begin{abstract}
Sea cucumbers is a group of marine invertebrates belonging to class holothuroidea. At this time, the hunting for sea cucumber is not just targetted on the expensive species, but also the cheap one. The exploitation pressure has caused population decline which can cause changes in their community structure. This research was aimed to understand the types of sea cucumber, analyze the structure of the community sea cucumber which includes the density of individuals, diversity index, the dominance index, interspecific and the dispersion pattern. Sample collection was done at night at the lowest tide in December, 2013. Based on the research activities in the coastal areas of Ondong, west Siau district, Siau-Tagulandang-Biaro regency, 7 species of holothuroidea were found: Holothuria atra, Holothuria leucospilota, Actinopyga echinites, Actinopyga lecanora, Bohadschia argus, Bohadschia marmorata and bohadschia vitiensis, respectively with mean individual density of $0.797 \mathrm{ind} / \mathrm{m}^{2}$, diversity index $\left(H^{\prime}=1.718\right)$, equity index or harmony $(e=0.883)$, dominance index $(C$ $=0.218$ ), interspecific association between 7 species forming 5 pairs of positive associations and 16 pairs of negative association andrandomdistribution.
\end{abstract}

Keywords : Structure communities, sea cucumber, Ondong, Sitaro

\section{ABSTRAK}

Teripangadalah sekelompokinvertebrata lautyang termasuk dalam kelasHolothuroidea. Pada saat ini, perburuanuntukteripangtidak hanyaditargetkanpada spesiesmahal, tetapi jugayang murah. Tekananeksploitasitelah menyebabkanpenurunan populasiyang dapat menyebabkanperubahan pada strukturkomunitasnya. Penelitian inibertujuan untukmemahami jenisteripang, menganalisisstrukturteripangyang meliputikepadatanindividu, indeks keanekaragaman, indeksdominasi, asosiasi antar spesies danpola penyebaran. Pengambilan sampeldilakukanpada malam harisaat surut terendahpada bulan Desember2013.Berdasarkankegiatan penelitiandiwilayah pesisirOndong, kecamatan SiaubaratKabupatenSiau-Tagulandang-Biaro, ditemukan 7spesiesteripang : Holothuriaatra, Holothurialeucospilota, Actinopygaechinites, Actinopygalecanora, Bohadschiaargus, Bohadschiamarmoratadanbohadschiavitiensis, masing-masing dengankepadatan individurata-rata0.797ind $/ \mathrm{m}$, indeks keanekaragaman $\left(\mathrm{H}^{\prime}=1.718\right)$, indekskemerataan atau keserasian $(e=0.883)$, indeksdominansi $(C=0.218)$, asosiasiantar 7spesiesmembentuk5pasangasosiasipositif dan16pasangasosiasinegatif danpenyebaran acak.

Kata kunci : Struktur komunitas, teripang, Ondong, Sitaro

\footnotetext{
${ }^{1}$ Bagian dari skripsi

${ }^{2}$ Mahasiswa Program Studi Manajemen Sumberdaya Perairan FPIK-UNSRAT

${ }^{3}$ Staf pengajar Fakultas Perikanan dan Ilmu Kelautan Universitas Sam Ratulangi
} 


\section{PENDAHULUAN}

Indonesia adalah negara kepulauan terbesar di dunia dengan luas 8,3 juta $\mathrm{km}^{2}$ yang terdiri dari 17.508 pulau dengan $81.000 \mathrm{~km}$ dari garis pantai. Perkiraan tangkapan tahunan lestari dari Indonesia sendiri, untuk sumber daya laut adalah sekitar 6,2 juta ton (Tuwo, 2004). Daerah pesisir dan laut Indonesia memberikan suatu habitat menguntungkan bagi spesies teripang. Teripang (holothurians) adalah kelompok hewan invertebrata laut dari kelas Holothuroidea (filum Echinodermata), dibedakan dalam enam bangsa (ordo) yaitu Dendrochirotida, Aspidochirotida, Dactylochirotida, Apodida, Molpadida, dan Elasipoda (Darsono, 2003). Teripang merupakan komponen penting dalam rantai makanan (food chain) di terumbu karang dan ekosistem asosiasinya pada berbagai tingkat struktur pakan (trophic levels). Teripang berperan penting sebagai pemakan deposit (deposit feeder) dan pemakan suspensi (suspensi feeder) (Wulandari dkk, 2012).

Trepang diakui sebagai kosa kata Indonesia teripang, dan dipakai sejajar dengan beche-de-mer (lafal Perancis). Dua kata ini merupakan istilah yang paling populer di pasar internasional, walaupun Jepang dan Cina sebagai konsumen utama teripang, memiliki istilah sendiri : iriko dan hai-som (Purwati, 2005).

Di perairan Indonesia saat ini terdapat sekitar 24 jenis teripang komersial, termasuk ke dalam kelas Holothuroidea, famili Holothuriidae dan Stichopodidae (Aziz, 1997). Komoditi ini mempunyai prospek cukup baik dan bernilai ekonomis penting, baik di pasar lokal maupun internasional karena kandungan atau kadar nutrisinya yang tinggi : protein $43 \%$, lemak $2 \%$, kadar air $17 \%$, mineral $21 \%$ dan kadar abu $7 \%$ (Martoyo dkk, 1994). Sebagai komoditas perdagangan teripang bahkan juga merupakan salah satu komoditas ekspor andalan Indonesia ke mancanegara. Permintaan akan komo- ditas teripang terutama untuk ekspor setiap tahunnya terus mengalami peningkatan, yang menyebabkan penangkapan dan perburuannya di perairan Indonesia berlangsung semakin intensif (Wisnubudi, 2013). Pada saat ini perburuan teripang tidak saja pada jenis-jenis yang berharga mahal, tapi juga terhadap jenis-jenis yang murah yang pada awalnya tidak menjadi perhatian. Tekanan eksploitasi terhadap jenis-jenis teripang tersebut telah menyebabkan populasi alaminya sangat menurun. Hal ini bisa menjadi masalah yang dilematis karena tidak ada usaha pengelolaan dan pelestariannya (Darsono 2007).

Ondong merupakan salah satu desa yang berada di Kecamatan Siau Barat, Kabupaten Kepulauan Siau, Tagulandang, Biaro (Sitaro) Provinsi Sulawesi Utara. Kabupaten Kepulauan Sitaro sendiri memiliki wilayah yang sebagian besar adalah wilayah laut, yang kaya akan potensi sumber daya kelautan serta mempunyai prospek yang dapat diandalkan di masa depan. Namun kondisi pemanfaatannya saat ini belum optimal. Ekspor perikanan laut Sitaro mencapai 6000 ton/tahun, pemanfaatan sumber perikanan ini masih tergolong usaha kecil dan tradisional (Buol, 2009). Walau pengetahuan mengenai status ekologi tentang teripang di wilayah Desa Ondong sampai saat ini belum tersedia, untuk itu hasil dari penelitian ini menyajikan gambaran umum mengenai komunitas teripang yang ada di kawasan tersebut.

Tujuan penelitian ini untuk mengetahui jenis-jenis teripang serta mengetahui struktur komunitas teripang yang meliputi kepadatan individu, indeks keanekaragaman spesies, indeks dominasi spesies, asosiasi antar spesies dan pola sebaran.

\section{MATERIAL DAN METODE}

Kegiatan penelitian ini dilaksanakan di kawasan pantai Desa Ondong. Untuk lokasi penelitian dapat dilihat pada Gambar 1. Pelaksanaan penelitian dilakukan pada bulan Desember 
tahun 2013. Untuk identifikasi sampel dilakukan di Laboratorium Hidrobioekologi dan Manajemen Sumberdaya Perairan (HBMSP) Fakultas Perikanan \& IImu Kelautan UNSRAT.

Pengambilan sampel menggunakan metode sampling dengan teknik transek garis dan kuadrat berukuran $1 \mathrm{~m}^{2} .3$ transek diletakkan secara tegak lurus terhadap garis pantai dengan panjang masing-masing transek $100 \mathrm{~m}$, dengan jarak antar transek 100m. Pada masing-masing transek diletakkan 10 kuadrat, yang ditempatkan berselangseling secara kontinyu sepanjang garis transek dengan jarak tiap kuadrat $10 \mathrm{~m}$, sehingga total jumlah penempatan kuadrat sebanyak 30 kuadrat.

Penentuan letak awal tiap transek menggunakan GPS (Global Position System), letak awal transek I berada pada titik koordinat $02^{\circ} 45^{\prime} 02^{\prime \prime} \mathrm{N}-125^{\circ}$ 21'34.1" E, transek II berada pada titik kordinat $02^{\circ} 45^{\prime} 05^{\prime \prime} \mathrm{N}-125^{\circ} 21^{\prime} 35.1^{\prime \prime} \mathrm{E}$ dan transek III berada pada titik kordinat $02^{\circ} 45^{\prime} 08^{\prime \prime} \mathrm{N}-125^{\circ} 21^{\prime} 36.3^{\prime \prime} \mathrm{E}$. Pengambilan sampel teripang dikerjakan pada saat surut terendah malam hari dengan menggunakan senter dan lampu petromaks sebagai penerang.

Teripang yang terdapat dalam setiap kuadrat dihitung, dicatat jumlah individu dan mikrohabitatnya. Untuk keperluan identifikasi, diambil satu atau dua individu untuk setiap spesies yang secara morfologi dianggap berbeda jenisnya, selanjutnya sampel setiap jenis (terdiri dari dua individu) dimasukkan secara terpisah ke dalam wadah plastik yang telah diisi alkohol $70 \%$ menjaga agar sampel tidak rusak, kemudian direkatkan penutupnya lalu diberi label. Untuk mengidentifikasi bentuk morfologi dan bentuk spikula dikerjakan di Laboratorium Hidrobioekologi dan Manajemen Sumberdaya Perairan (HBMSP) Fakultas Perikanan \& IImu Kelautan UNSRAT. Sebagai penuntun identifikasi menggunakan Clark dan Rowe (1971).

Adapun prosedur identifikasi selain pengamatan morfologi juga dilakukan pengamatan spikula sebagai berikut :
1. Membuat sayatan tipis pada dinding tubuh teripang yang telah dibersihkan dari segala kotoran yang menempel, kemudian hasil sayatan tersebut dimasukkan kedalam wadah sampel yang berisikan $5 \mathrm{ml}$ aquades dan diberi cairan bayclin $\pm 10 \mathrm{ml}$, setelah itu dibiarkan beberapa saat sampai terjadi reaksi yakni hancurnya jaringan.

2. Sayatan teripang yang telah hancur akan meninggalkan endapan berupa bentuk kristal yang terdiri dari endapan spikula dan kapur, kemudian endapan ini diambil dengan menggunakan pipet lalu diletakkan di atas kaca objek yang telah disediakan dilanjutkan dengan pengamatan di bawah mikroskop.

3. Mikroskop yang disiapkan diatur pada pembesaran yang sesuai.

4. Spikula yang tampak di bawah mikroskop, difoto bentuknya menggunakan kamera digital.

5. Selanjutnya bentuk spikula yang tampak di bawah mikroskop dicocokkan pada buku pedoman identifikasi gambar bentuk spikula Clark dan Rowe (1971).

Beberapa indeks yang digunakan untuk mengetahui struktur komunitas teripang (Holothuroidea) yaitu : kepadatan, indeks keanekaragaman, kemerataan spesies dan indeks dominasi(Cox, 1967).

Asosiasi antar spesies dianalisis menggunakan koefisien korelasi titik (Poole, 1974). Berdasarkan tabel kontingensi $2 \times 2$, koefisien korelasi (V) dihitung sebagai berikut :

$$
V=\frac{a d-b c}{\sqrt{(a+b)(a+c)(b+d)(c+d)}}
$$

Pola sebaran ditentukan melalui hubungan antara varians $\left(\sigma^{2}\right)$ dan ratarata aritmatik $(\mu)$ : sebaran acak jika $\sigma^{2}=$ $\mu$ (sebaran Poisson), sebaran teratur jika $\sigma^{2}<\mu$ (sebaran binomial positif), dan sebaran mengelompok jika $\sigma^{2}>\mu$ (sebaran binomial negatif). Rasio varians rata-rata atau indeks dispersi (I) akan medekati 1 (satu) jika cocok 
dengan sebaran Poisson. Indeks dispersi diformulakan sebagai berikut (Elliott, 1977):

$$
I=s^{2} / m,
$$

di mana: $s^{2}=$ varians contoh $(\Sigma(x-$ $m)^{2}(n-1), \quad x=$ jumlah individu dalam setiap unit sampling (kuadrat), $n=$ jumlah unit sampling (kuadrat), dan $m=$ rata-rata contoh (rata-rata jumlah individu dalam kuadrat). Nilai indeks dispersi sering berbeda dengan nilai satu dan signifikasi perbedaannya diuji dengan uji $X^{2}$ jika $n<31$ (Elliott, 1977):

$$
x^{2}=I(n-1)
$$

Jika nilai $X^{2}$ ini terletak di antara nilai tabel $X^{2} p=0,975$ (batas bawah) dan $p$ $=0,025$ (batas atas) untuk derajad bebas $=n-1$ dan taraf nyata $\alpha=0,05$, maka kecocokkan dengan sebaran Poisson dapat diterima pada tingkat peluang $95 \%$ atau dengan kata lain individu dalam populasi menyebar secara acak. Jika nilai $x^{2}$ terletak di atas batas atas nilai tabel $x^{2}$, maka individu menyebar secara mengelompok; dan sebaliknya jika nilai tersebut terletak di bawah batas bawahnya maka pola sebaran contoh adalah teratur.

\section{HASIL DAN PEMBAHASAN}

Pengamatan mikrohabitat meliputi kehadiran teripang di pasir, rumput laut dan karang. Pada mikrohabitat pasir, teripang ditemukan membenamkan sebagian tubuhnya ke dalam pasir. Pada mikrohabitat rumput laut, di mana pada saat surut masih tersisa genangan air ditemukan teripang menutupi tubuhnya di antara tegakan rumput laut. Pada mikro habitat karang teripang ditemukan di atas atau di bawah bongkahan karang mati yang ditumbuhi alga dan di celah karang mati. Berdasarkan teknik/metode garis transek dengan kuadrat $(1 \mathrm{~m} \times 1 \mathrm{~m})$, ditemukan 7 spesies teripang. Klasifikasi dan ciri-ciri morfologi serta bentuk spikula tiap spesies teripang sperti yang diuraikan sebagai berikut :

\section{Holothuria (Halodeima) atra Jaeger, 1957

$$
\begin{array}{cl}
\text { Kelas } & : \text { Holothuroidea } \\
\text { Ordo } & : \text { Aspidochirotida } \\
\text { Famili } & : \text { Holothuridae } \\
\text { Genus } & : \text { Holothuria } \\
\text { Spesies } & \text { Holothuria atra }
\end{array}
$$

\section{Deskripsi umum}

Badan berbentuk bulat panjang dengan punggung kehitaman berbintik putih atau kuning, jika diraba tubuhnya agak kasar. Spikula berbentuk meja (tables) tampak samping dan roset (rossete) merupakan batang pendek yang ujungnya bercabang cabang pendek. Teripang ini banyak ditemukan di sekitar bebatuan atau pasir terbuka di perairan laut, atau di kolam kecil. Umumnya hidup di perairan yang dangkal hingga kedalaman 100 kaki. Jika teripang ini diambil dari air, bentuknya terlihat padat, tetapi ketika air telah hilang, maka akan berbentuk seperti jeli dan mengeluarkan ususnya yang beracun (Anonimous, 2004).

\section{Holothuria}

\section{(Mertensiothuria)leucospilota} Brandt, 1835

$\begin{array}{cl}\text { Kelas } & : \text { Holothuroidea } \\ \text { Ordo } & : \text { Aspidochirotida } \\ \text { Famili } & : \text { Holothuridae } \\ \text { Genus } & : \text { Holothuria } \\ \text { Spesies } & : \text { Holothuria leucospilota } \\ \text { Deskripsi umum }\end{array}$

Bentuk tubuh bulat panjang, warna tubuh umumnya berwarna cokelat tua kemerahan. Spikula berbentuk meja (tables) dan bentuk kancing (buttons) dengan jumlah lubang yang bervariasi tersusun dalam dua baris, sering ditemukan pada daerah terumbu karang, lebih khusus lagi ditemukan di dasar laut berpasir atau di bawah bebatuan dengan kedalaman hingga 3 meter (Anonimous, 2001).

\section{Actinopyga echinites (Jaeger, 1833)

$\begin{array}{cl}\text { Kelas } & \text { : Holothuroidea } \\ \text { Ordo } & : \text { Aspidochirotida } \\ \text { Famili } & : \text { Holothuridae } \\ \text { Genus } & : \text { Actinopyga } \\ \text { Spesies } & \text { : Actinopyga echinites }\end{array}$




\section{Deskripsi umum}

Bentuk tubuh bulat lonjong, memiliki tonjolan-tonjolan kecil dibagian punggung, warna tubuh hitam keabuabuan bercampur coklat, mulut dan anus terletak pada bagian anterior dan posterior. Spikula berbentuk roset (rosette) batang panjang dengan ujung bercabang sederhana. Teripang jenis ini umumnya ditemukan di dasar perairan pasir berbatu atau karang.

\section{Actinopyga lecanora (Jaeger,} 1833)

$\begin{array}{cl}\text { Kelas } & : \text { Holothuroidea } \\ \text { Ordo } & : \text { Aspidochirotida } \\ \text { Famili } & : \text { Holothuridae } \\ \text { Genus } & : \text { Actinopyga } \\ \text { Spesies } & : \text { Actinopyga lecanora }\end{array}$

\section{Deskripsi umum}

Bentuk tubuh agak lonjong, jika diraba terasa agak kasar karena memiliki tonjolan-tonjolan di bagian punggungnya, warna tubuh kuning emas berbintik hitam. Spikula berbentuk roset (rosettes) batang pendek dengan ujung bercabang pendek. Teripang jenis ini dapat ditemukan di daerah bebatuan atau patahan terumbu karang.

\section{Bohadschia argus Jaeger, 1833}

$$
\begin{array}{cl}
\text { Kelas } & : \text { Holothuroidea } \\
\text { Ordo } & : \text { Aspidochirotida } \\
\text { Famili } & : \text { Holothuridae } \\
\text { Genus } & : \text { Bohadschia } \\
\text { Spesies } & : \text { Bohadschia argus }
\end{array}
$$

\section{Deskripsi umum}

Badan berbentuk bulat panjang, punggung terdapat warna coklat kehitam-hitaman, warna perut kuning putih susu dan terdapat bercak-bercak, badan jika di raba terasa agak kasar. Spikula berbentuk roset (rosettes) bercabang banyak dan granula. Umumnya dapat ditemukan di dasar perairan karang berpasir halus.

\section{Bohadschia marmorata Jaeger, 1833
Ordo : : Aspidochirotida
Famili : Holothuridae
Genus : Bohadschia \\ Kelas : Holothuroidea \\ Spesies : Bohadschia marmorata}

\section{Deskripsi umum}

Ditandai dengan tubuh yang berwarna kekuning-kuningan disertai dengan gelang lebar berwarna cokelat. Papillae halus dan tersebar merata di seluruh permukaan tubuh. Spikula berbentuk batang bercabang sederhana dan granula. Hidup di antara vegetasi tegakan lamun yang umumnya dangkal dan mempunyai substrat pasir dan kerikil dari pecahan batu karang (Anonimous, 2007).

\section{Bohadschia vitiensis (Semper, 1868)
Kelas : Holothuroidea
Ordo : : Aspidochirotida
Famili : Holothuridae
Genus : Bohadschia
Spesies : Bohadschia vitiensis

\section{Deskripsi umum}

Bentuk tubuh bulat lonjong, ditandai warna tubuh berwarna kekuningkuningan disertai dengan bintik-bintik hitam di seluruh tubuhnya, jika diraba tubuhnya agak lembek. Spikula berbentuk batang(rods) bercabang sederhana. Pada umumya dapat ditemukan di dasar perairan berpasir serta memiliki tegakan lamun.

Semua spesies teripang ini termasuk dalam famili Holothuridae. Spesies-spesies ini tergolong dalam ordo Aspidochirotida. Seperti yang diuraikan Bakus (1973) dalam Yusron dkk, (2004) ordo Aspidochirotida merupakan karakteristik yang hidup di perairan tropis yang jernih. Hal ini juga diperkuat oleh Hyman (1955) mengemukakan bahwa daerah Indo-Pasifik bagian barat merupakan daerah yang kaya akan jenis teripang dari genera Holothuria, Stichopus dan Actinopyga.

Total hasil analisis kepadatan individu dari seluruh spesies yaitu $0,797 \mathrm{ind} / \mathrm{m}^{2}$. Spesies teripang yang memiliki kepadatan tertinggi terdapat pada spesies Holothuria atra yaitu $0,300 \mathrm{ind} / \mathrm{m}^{2}$. Bakus (2007) menyatakan bahwa $H$. atra mempunyai mekanisme pertahanan diri yang tinggi, di mana spesies ini menempeli tubuhnya dengan butiran-butiran pasir. Pasir 
yang menempel pada tubuh $H$. atra memantulkan cahaya dan membuat suhu tubuhnya lebih rendah. Tingginya tingkat pertahanan diri dari teripang ini, maka tingkat kehadirannya juga tinggi. Spesies $H$. leucospilota, Actinopyga echinites, A. lecanora, Bohadschia argus, $B$. marmorata, $B$. vitiensis memiliki kepa-datan yang relatif rendah yaitu $0,033-0,133 i n d / \mathrm{m}^{2}$. Kepadatan relatif yang rendah disebabkan kurangnya kemampuan bersaing dalam menempati habitat. Selain itu diduga akibat adanya penangkapan berlebihan dari masyarakat setempat, dikarenakan spesies-spesies ini merupakan spesies yang memiliki nilai ekonomis.

Hasil kepadatan ini rendah jika dibandingkan dengan hasil penelitian Umar, (2009) di perairan Likupang Sulawesi Utara menemukan 10 spesies teripang dengan kepadatan tertinggi dari spesies Bohadschia argus yaitu $0,07 \mathrm{ind} / \mathrm{m} 2$. Sedangkan spesies $B$. marmorata, Holothuria. atra, $H$. hilla, $H$. scabra, $H$. discrepans, Stichopus. variegates, dan Opheodesoma grisea memiliki kepadatan yang relatif rendah berkisar antara 0,01-0,03ind $/ \mathrm{m}^{2}$. Penelitian Tamanampo dkk, (1989) di perairan Pulau Bunaken Sulawesi Utara menemukan 10 spesies dengan kepadatan tertinggi pada jenis Stichopus chloronotus $\left(1,02 \mathrm{ind} / \mathrm{m}^{2}\right), \quad B$. argus $\left(0,97 \mathrm{ind} / \mathrm{m}^{2}\right)$ dan $H$. atra $\left(0,78 \mathrm{ind} / \mathrm{m}^{2}\right)$. Yusron, (2009) di perairan Minahasa (Sulawesi Utara) di lokasi Kima Bajo, Wori dan Tiwoho nilai kepadatan cukup tinggi pada spesies Holothuria atra $\left(1,26 \mathrm{ind} / \mathrm{m}^{2}\right)$ dan Bohadschia argus $\left(0,72 \mathrm{ind} / \mathrm{m}^{2}\right)$. Yusron dkk, (2004) di perairan Kai Kecil, Maluku Tenggara mencatat kepadatan teripang yang tertinggi dari jenis $H$. atra $(1,03 i n d / m 2)$, B. marmorata $(0,97 \mathrm{ind} / \mathrm{m} 2)$ dan $H$. Edulis $\left(0,81 \mathrm{ind} / \mathrm{m}^{2}\right)$.

\section{Keanekaragaman, Kemerataan dan Dominasi Spesies}

Indeks keanekaragaman dapat digunakan untuk mencirikan hubungan kelompok genus dalam komunitas. Indeks keanekaragaman yang dipergu- nakan adalah indeks ShannonWienner. Berdasarkan hasil analisis nilai indeks keanekaragaman spesies( $\left(H^{\prime}\right)$ dari komunitas teripang di lokasi penelitian diperoleh1,718. Ini menun-jukkan bahwa nilai indeks keanekara-gaman spesies teripang tergolong sedang. Sugiarto (1994) mengatakan bahwa suatu komunitas dikatakan mempunyai keanekaragaman (diversi-tas) yang tinggi jika komunitas itu disu-sun oleh banyak spesies dominan, sebaliknya jika komunitas itu disusun sangat sedikit spesies dominan maka keanekaragamannya rendah.

Berdasarkan hasil analisis nilai indeks kemerataan/keserasian diperoleh nilai indeks $\mathrm{e}=0,883(88,3 \%)$. Jika dilihat secara umum, nilai indeks kemerataan jenis teripang pada lokasi penelitian cenderung mendekati 1 yang berarti komunitas berada dalam kondisi yang cukup stabil.Nilai indeks kemerataan jenis dapat menggambarkan kestabilan suatu komunitas. Suatu komunitas bisa dikatakan stabil bila mempunyai nilai indeks kemerataan jenis mendekati angka 1, dan dikatakan tidak stabil jika mempunyai nilai indeks kemerataan jenis yang mendekati angka 0 . Sebaran fauna seimbang atau merata apabila mempunyai nilai indeks kemerataan jenis yang berkisar antara 0,6-0,8 (Odum, 1963). Sebaran jenis suatu organisme berkaitan erat dengan dominasi jenis, Semakin besar nilai indeks dominansi (C), maka semakin besar kecenderungan adanya jenis tertentu yang mendominasi. Berdasarkan hasil analisis nilai indeks dominasi spesies teripang diperoleh 0,218 , menunjukkan tidak adanya spesies yang mendominasi.

\section{Asosiasi Antar Spesies}

Berdasarkan hasil analisis nilai indeks asosiasi antar 7 spesies teripang membentuk 2 kelompok pasangan asosiasi (Tabel 3), di mana terdapat 5 pasang asosiasi positif, dengan kekuatan asosiasi berkisar antara 0,015 $-0,288$. Bentuk asosiasi positif terdapat 
3 kemungkinan yang akan terjadi seperti yang dikemukakan oleh Schluther (1984) dalam Ludwig dan Reynolds (1988), bahwa :

a. Spesies mempunyai suatu respon yang sama terhadap suplai sumberdaya yang tidak terbatas.

b. Spesies saling mempertinggi peluang survival.

c. Spesies berfluktuasi serempak dalam merespon sumberdaya yang terbatas.

Sedangkan asosiasi negatif terdapat 16 pasang spesies dengan kekuatan asosiasi berkisar antara 0,049 -0,147 dan pada bentuk asosiasi ini juga terdapat 3 kemungkinan seperti yang dikemukakan oleh Schluther (1984) dalam Ludwig dan Reynolds (1988), bahwa :

a. Spesies mempunyai perbedaan kebutuhan sumberdaya .

b. Spesies bersaing menggunakan sumberdaya secara eksklusif.

c. Persaingan antar spesies kadangkadang berakibat pengusiran.

\section{Pola Sebaran}

Berdasarkan hasil analisis nilai rasio varians rata-rata atau indeks dispersi (I) pola penyebaran spesies teripang dilokasi penelitian menunjukkan pola sebaran acak (random) dikarenakan nilai indeks dispersi (I) mendekati 1 (satu). Pola sebaran acak dari individu-individu populasi suatu spesies dalam suatu habitat menunjukkan bahwa terdapat keseragaman (homogenity) dalam lingkungan dan atau pola tingkah laku yang tidak selektif. Tipe penyebaran ini dapat diharapkan di alam apabila banyak faktor kecil yang bertindak bersamasama terhadap populasi (Odum, 1993).

\section{KESIMPULAN}

Spesies teripang yang ditemukan berjumlah 7 spesies yaitu Holothuria (Halodeima) atra, H. (mertensiothuria) leucospilota, Actinopyga echinites, A. lecanora, Bohadschia argus, $B$. marmorata dan $B$. vitiensis. Total kepadatan individu dari keseluruhan spesies $0,797 \mathrm{ind} / \mathrm{m}^{2}$, dengankepadatan tertinggi pada spesies Holothuria atra $\left(0,300 \mathrm{ind} / \mathrm{m}^{2}\right)$ sedangkan 6 spesies lainnya memiliki kepadatan individu berkisar 0,033-0,133 ind $/ \mathrm{m}^{2}$.

Nilai indeks keanekaragaman diperoleh 1,718, indeks kemerataan spesies 0,883 dan indeks dominasi spesies diperoleh 0,218, menunjukkan tidak ada spesies yang mendominasi. Nilai asosiasi antar spesies terdapat 5 pasang asosiasi positif dan 16 pasang asosiasi negative dengan pola penyebaran mengikuti pola sebaran acak.

\section{DAFTAR PUSTAKA}

Anonimous, 2001. Partnership for Global Education: Queensland Term 2001 http://people.hws.edu/field guide/ show.asp?ID=121 31 Maret 2013 jam 21.02

Anonimous, 2004. Echinoderms. Indonesians clearing house mechanism for biodiversity http://www. bluforman.com/intertidal/test/species /speciesPages/groups/echinoderms/ Holothuriaatra.html 31 maret 2013 jam 20.06

Anonimus, 2007. Program rehabilitasi dan pengelolaan terumbu karang http://www.coremap.or.id/datin/echin o/index.php?keyid=36\&act=detail 23 mei 2014 jam 17.00

Aziz, A. 1997. Status Penelitian Teripang Komersial di Indonesia. Balitbang Biologi Laut, Puslitbang Oseanologi-LIPI, Jakarta. 9-19 hal.

Bakus, G.J. 2007. A comparison of some population density sampling technique for biodiversity, conservation, environmental impact studies. J Biodiversity Concerv 16: 2445-2455.

Buol, R. 2009. Hasil Pencapaian Kinerja Perekonomian Daerah Semasa Pemerintahan Penjabat Bupati 
Clark M. dan F.W.E Rowe. 1971. Monograph of Shallow - Water Indo - West Pacific Echinoderms. Trustees of The British Museum (Natural History). London. 238 hal.

Cox, G.W. 1967. Laboratory Manual of General Ecology. Brown Company Publisher. USA. 165 hal.

Darsono, P. 2003. Sumber Daya Teripang dan Pengelolaannya. Bidang Sumberdaya Laut, Pusat Penelitian Oseanografi-LIPI, Jakarta. 1-9 hal.

Darsono, P. 2007. Teripang (Holothuroidea): Kekayaan Alam Dalam Keragaman Biota Laut. Oseana, Volume XXXII, Nomor 2. Bidang Sumberdaya Laut, Pusat Penelitian Oseanografi-LIPI, Jakarta. 1-10 hal.

Elliot, J. M. 1977. Some methods for the statistical analysis of samples of benthic invertebrates. Freshwater Biological Association, Scientific Publication 25. Ferry House.

Hyman, L. H. 1955. The Invertebrates: Echinodermata, the Coelomate bilateral. Vol. 4. McGraw - Hill Book, Co., Inc., New York : 763 pp.

Ludwig. J. A dan J. F. Reynolds. 1988. Statistical Ecology. A primer on methods and computing. Jhon Wiley \& Sons. New York. Hal 337.

Martoyo, J., A. Nugroho dan Winanto. 1994. Budidaya Teripang. Penerbit Penebar Swadaya. Jakarta. 69 hal.

Odum, E.P. 1963. Ecology. The University of Georgia, USA: 152 pp.

Odum, E.P., 1993. Dasar - dasar Ekologi. Edisi Ketiga. Cetakan Pertama. Gadjah Mada University Press. Yogyakarta. 697 hal.

Poole, R.W., 1974. An Introduction to Quantitative Ecology. Mc Gra Hill Book Company. 397 hal.

Purwati, P. 2005. Teripang Indonesia : Komposisi Jenis dan Sejarah
Perikanan. Oseana, Volume XXX, Nomor 2. Bidang Sumberdaya Laut, Pusat Penelitian Oseanografi-LIPI, Jakarta. 11-18 hal.

Sugiarto, A. 1994. Ekologi Kuantitatif (Metode Analisis Populasi dan Komunitas). Usaha Nasional. Surabaya. 173 hal.

Tamanampo, F.W.S., M. Rondo dan M.S. Salaki. 1989. Potensi dan komunitas teripang (Holothuroidea) di Rataan terumbu karang pulau Bunaken, Sulawesi Utara. Jur. Fak. Per. Unsrat I (I) : 25-32.

Tuwo, A. 2004. Status of sea cucumber fisheries and farming in Indonesia. In: Advances in sea cucumber aquaculture and management. (A. Lovatelli, eds.). FAO Fisheries Technical Paper. 1-425 hal.

Umar, M. F. 2009. Struktur Komunitas Teripang (Holothuroidea) Di Perairan Likupang Depan Labora-torium Basah Fpik UNSRAT Kab. Minahasa Utara. 42 hal.

Wisnubudi, G. 2013. Keanekaragaman dan Kelimpahan Teripang (Holothuriodea) Serta Potensinya Di Pulau Kotok Besar, Taman Nasional Laut Kepulauan Seribu (Tnkps). Fakultas Biologi Universitas Nasional. Jakarta. 1-14 hal.

Wulandari, N. M. Krisanti dan D. Elfidasari. 2012. Keragaman Teripang asal Pulau Pramuka, Kepulauan Seribu Teluk Jakarta. Jurnal Unnes of Life science 1 (2). Fakultas Sains dan Teknologi Universitas Al Azhar Indonesia. 133139 hal.

Yusron, E. dan Pitra W. 2004. Struktur Komunitas Teripang (Holothuroidea) di Beberapa Perairan Pantai Kai Besar, Maluku Tenggara. Jurnal Makara, Sains, Vol. 8, No. 1, April $2004: 15-20$

Yusron, E. 2009. Keanekaragaman Jenis Teripang (Holothuroidea) di Perairan Minahasa Utara Sulawesi 
Utara. Oseanologi dan Limnologi di Indonesia. LIPI, Jakarta. 19-28 hal.

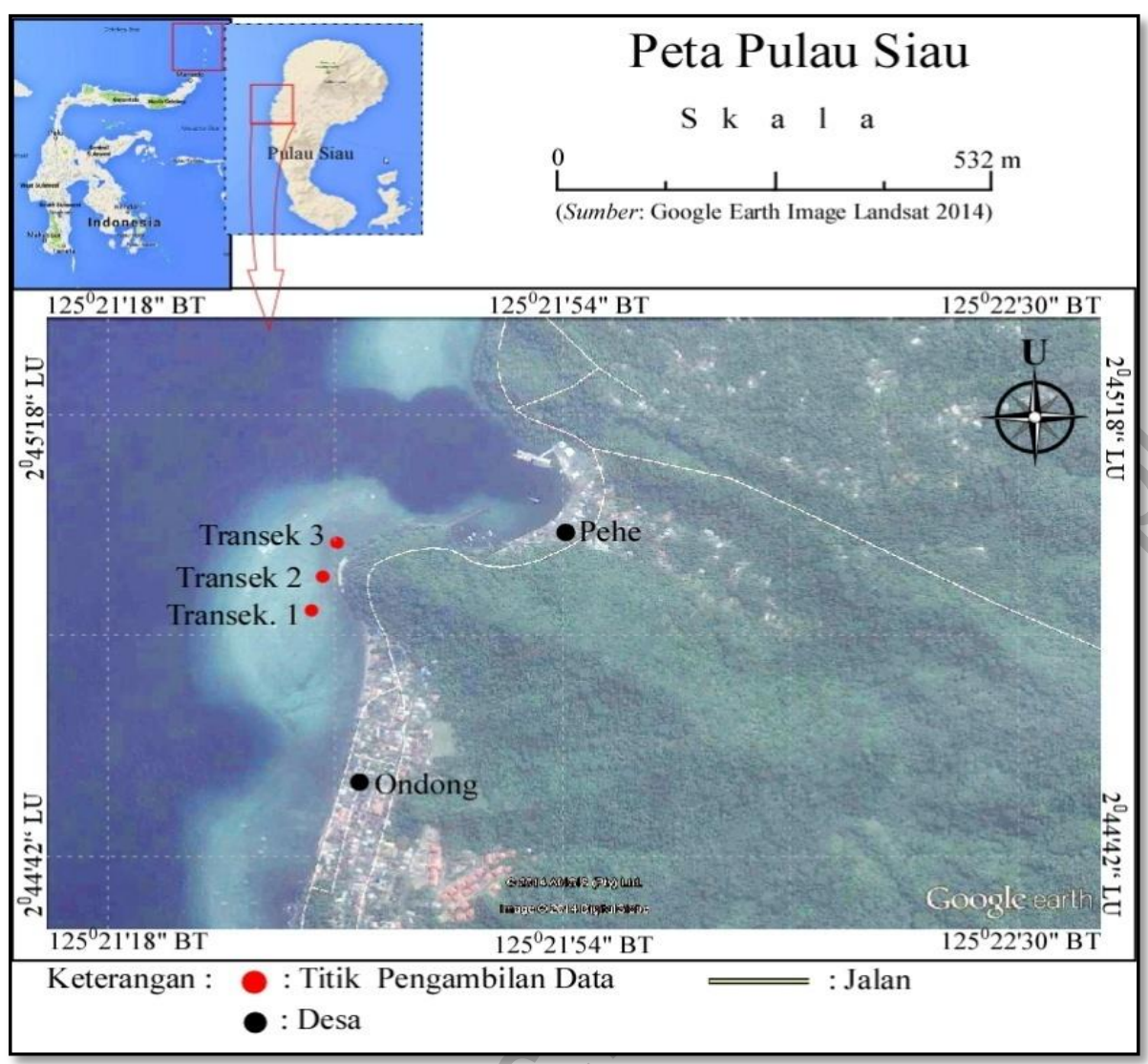

Gambar 1. Peta lokasi penelitian

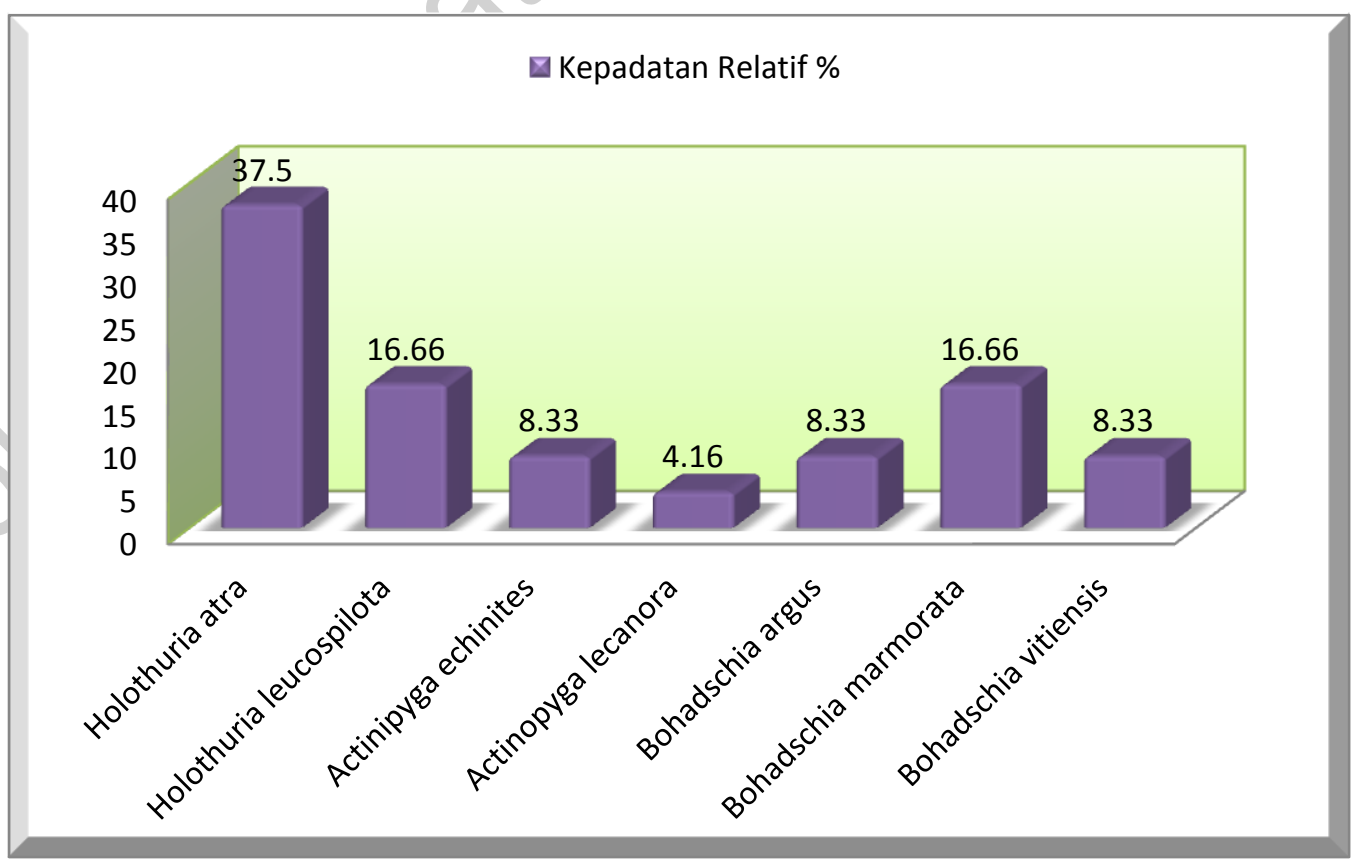

Gambar 2. Kepadatan relatif individu spesies teripang 
Tabel 1. Kepadatan individu (ind $/ \mathrm{m}^{2}$ ) dan kepadatan relatif (\%) spesies teripang yang di temukan di lokasi penelitian pada bulan Desember 2013.

\begin{tabular}{|c|l|c|c|c|}
\hline No & \multicolumn{1}{|c|}{ Nama Spesies } & $\begin{array}{c}\text { Jumlah Individu } \\
\text { Setiap Spesies }\end{array}$ & $\begin{array}{c}\text { Kepadatan } \\
\text { Individu }\end{array}$ & $\begin{array}{c}\text { Kepadatan } \\
\text { Relatif (\%) }\end{array}$ \\
\hline 1 & Holothuria atra & 9 & 0,300 & 37,5 \\
\hline 2 & Holothuria leucospilota & 4 & 0,133 & 16,66 \\
\hline 3 & Actinipyga echinites & 2 & 0,066 & 8,33 \\
\hline 4 & Actinopyga lecanora & 1 & 0,033 & 4,16 \\
\hline 5 & Bohadschia argus & 2 & 0,066 & 8,33 \\
\hline 6 & Bohadschia marmorata & 4 & 0,133 & 16,66 \\
\hline 7 & Bohadschia vitiensis & 2 & 0,066 & 8,33 \\
\hline \multicolumn{2}{|c}{} & $\mathbf{2 4}$ & $\mathbf{0 , 7 9 7}$ & $\mathbf{1 0 0} \%$ \\
\hline
\end{tabular}

Tabel 2. Indeks keanekaragaman dan kemerataan spesies teripang yang ditemukan di lokasi penelitian pada bulan Desember 2013.

\begin{tabular}{|c|l|c|c|c|c|}
\hline \multirow{2}{*}{ No } & \multicolumn{5}{|c|}{ Indeks Keanekaragaman } \\
\cline { 2 - 6 } & \multicolumn{1}{|c|}{ Spesies } & $\mathbf{n i}$ & $\mathbf{n i} / \mathbf{N}$ & $\mathbf{l n}(\mathbf{n i} / \mathbf{N})$ & $(\mathbf{n i} / \mathbf{N})(\mathbf{l n ~ n i} / \mathbf{N})$ \\
\hline 1. & Holothuria atra & 9 & 0,375 & $-0,98082$ & $-0,3678$ \\
\hline 2. & Holothuria leucospilota & 4 & 0,1666 & $-1,79215$ & $-0,2985$ \\
\hline 3. & Actinipyga echinitess & 2 & 0,0833 & $-2,48530$ & $-0,2070$ \\
\hline 4. & Actinopyga lecanora & 1 & 0,0416 & $-3,17965$ & $-0,1322$ \\
\hline 5. & Bohadschia argus & 2 & 0,0833 & $-2,48530$ & $-0,2070$ \\
\hline 6. & Bohadschia marmorata & 4 & 0,1666 & $-1,79215$ & $-0,2985$ \\
\hline 7. & Bohadschia vitiensis & 2 & 0,0833 & $-2,48530$ & $-0,2070$ \\
\hline & $\mathbf{N}$ & $\mathbf{2 4}$ & & & \\
\hline & $\mathbf{H}$ & & & & $\mathbf{- 1 , 7 1 8}$ \\
\hline
\end{tabular}

$$
\begin{aligned}
& H^{\prime}=-\sum_{i=1}^{s}(n i / N) \ln (n i / N)=1,718 \quad \text { H Max }=\ln 7=1,945 \\
& e=H^{\prime} / \ln s=0,883
\end{aligned}
$$

Tabel 3. Asosiasi antar spesies teripang

\begin{tabular}{|c|c|c|c|c|c|c|c|c|}
\hline & \multicolumn{9}{|c|}{ Spesies } \\
\hline & & A & B & C & D & E & F & G \\
\cline { 2 - 9 } & $\mathbf{A}$ & & 0,015 & $-0,147$ & $-0,102$ & 0,168 & 0,015 & $-0,147$ \\
\cline { 2 - 9 } & $\mathbf{B}$ & & & 0,288 & $-0,072$ & 0,288 & $-0,153$ & $-0,104$ \\
\cline { 2 - 9 } & $\mathbf{C}$ & & & & $-0,049$ & $-0,071$ & $-0,104$ & $-0,071$ \\
\cline { 2 - 9 } Spesies & $\mathbf{D}$ & & & & & $-0,049$ & $-0,072$ & $-0,049$ \\
\cline { 2 - 9 } & $\mathbf{E}$ & & & & & & $-0,104$ & $-0,071$ \\
\cline { 2 - 9 } & $\mathbf{F}$ & & & & & & & $-0,104$ \\
\hline
\end{tabular}


Tabel 4. Pola sebaran teripang (Holothuroidea) yang ditemukan di lokasi penelitian pada bulan Desember 2013.

\begin{tabular}{|c|c|c|c|c|c|c|c|}
\hline Kuadrat & $\begin{array}{l}\text { Holothuria } \\
\text { atra }\end{array}$ & $\begin{array}{l}\text { Holothuria } \\
\text { leucospilota }\end{array}$ & $\begin{array}{c}\text { Actinopyga } \\
\text { echinites }\end{array}$ & $\begin{array}{l}\text { Actinopyga } \\
\text { lecanora }\end{array}$ & $\begin{array}{l}\text { Bohadschia } \\
\text { argus }\end{array}$ & $\begin{array}{l}\text { Bohadschia } \\
\text { marmorata }\end{array}$ & $\begin{array}{c}\text { Bohadschia } \\
\text { vitiensis }\end{array}$ \\
\hline 1 & 0 & 0 & 0 & 0 & 0 & 0 & 0 \\
\hline 2 & 0 & 0 & 0 & 0 & 0 & 0 & 0 \\
\hline 3 & 2 & 0 & 0 & 0 & 0 & 0 & 0 \\
\hline 4 & 0 & 0 & 0 & 0 & 0 & 0 & 0 \\
\hline 5 & 0 & 1 & 0 & 0 & 0 & 0 & 0 \\
\hline 6 & 0 & 0 & 0 & 0 & 0 & 1 & 0 \\
\hline 7 & 1 & 0 & 0 & 0 & 1 & 0 & 0 \\
\hline 8 & 0 & 1 & 1 & 0 & 0 & 0 & 0 \\
\hline 9 & 0 & 0 & 0 & 0 & 0 & 0 & 0 \\
\hline 10 & 1 & 0 & 0 & 0 & 0 & 1 & 0 \\
\hline 11 & 0 & 0 & 0 & 0 & 0 & 0 & 0 \\
\hline 12 & 0 & 0 & 0 & 0 & 0 & 0 & 1 \\
\hline 13 & 0 & 0 & 0 & 0 & 0 & 0 & 0 \\
\hline 14 & 2 & 0 & 0 & 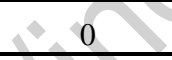 & 0 & 0 & 0 \\
\hline 15 & 0 & 0 & 0 & 1 & 0 & 0 & 0 \\
\hline 16 & 0 & 0 & 0 & 0 & 0 & 1 & 0 \\
\hline 17 & 0 & 1 & 0 & 0 & 1 & 0 & 0 \\
\hline 18 & 1 & 0 & 0 & 0 & 0 & 0 & 0 \\
\hline 19 & 0 & 0 & 1 & 0 & 0 & 0 & 0 \\
\hline 20 & 0 & 0 & $\begin{array}{r}\quad 0 \\
\end{array}$ & 0 & 0 & 0 & 0 \\
\hline 21 & 0 & 0 & 0 & 0 & 0 & 0 & 0 \\
\hline 22 & 1 & 1 & 0 & 0 & 0 & 0 & 0 \\
\hline 23 & 0 & 0 & 0 & 0 & 0 & 0 & 0 \\
\hline 24 & 0 & 0 & 0 & 0 & 0 & 0 & 1 \\
\hline 25 & 0 & 0 & 0 & 0 & 0 & 0 & 0 \\
\hline 26 & 1 & 0 & 0 & 0 & 0 & 0 & 0 \\
\hline 27 & 0 & 0 & 0 & 0 & 0 & 1 & 0 \\
\hline 28 & 0 & 0 & 0 & 0 & 0 & 0 & 0 \\
\hline 29 & 0 & 0 & 0 & 0 & 0 & 0 & 0 \\
\hline 30 & 0 & 0 & 0 & 0 & 0 & 0 & 0 \\
\hline$N$ & 30 & 30 & 30 & 30 & 30 & 30 & 30 \\
\hline$M$ & 0,3 & 0,133333333 & 0,066667 & 0,0333333 & 0,06666667 & 0,13333333 & 0,06666667 \\
\hline$S^{2}$ & 0,3551724 & 0,11954023 & 0,064368 & 0,0333333 & 0,06436782 & 0,11954023 & 0,06436782 \\
\hline$I$ & 1,183908 & 0,896551724 & 0,965517 & 1 & 0,96551724 & 0,89655172 & 0,96551724 \\
\hline$X^{2}$ & 34,333333 & 26 & 28 & 29 & 28 & 26 & 28 \\
\hline $\begin{array}{c}\text { Pola } \\
\text { sebaran }\end{array}$ & Acak & Acak & Acak & Acak & Acak & Acak & Acak \\
\hline
\end{tabular}

